\title{
Prospects for Policy Advances in Science and Technology in the Gulf Arab States: The Role for International Partnerships
}

\author{
David P. Hajjar ${ }^{1,2}$, George W. Moran ${ }^{1}$, Afreen Siddiqi ${ }^{2,3}$, Joshua E. Richardson ${ }^{1}$, Laura D. Anadon ${ }^{2} \&$ Venkatesh \\ Narayanamurti ${ }^{2,4}$ \\ ${ }^{1}$ Weill Cornell Medical College, Cornell University, New York, NY, USA \\ ${ }^{2}$ John F. Kennedy School of Government, Harvard University, Cambridge, MA, USA \\ ${ }^{3}$ Engineering Systems Division, Massachusetts Institute of Technology, MA, USA. \\ ${ }^{4}$ Harvard School of Engineering and Applied Sciences, Harvard University, Cambridge, MA, USA \\ Correspondence: David P. Hajjar, Weill Cornell Medical College, Cornell University, New York, NY, USA \& John \\ F. Kennedy School of Government, Harvard University, Cambridge, MA, USA. E-mail: dphajjar@med.cornell.edu
}

Received: May 19, 2014

doi:10.5430/ijhe.v3n3p45
Accepted: June 18, 2014

Online Published: June 20, 2014

URL: http://dx.doi.org/10.5430/ijhe.v3n3p45

\begin{abstract}
Science, technology, engineering and mathematics (STEM) policies in the Gulf Arab States are as diverse as the individual economies and political processes that characterize its member states. During the past decade, a number of expert review groups have argued that science and technology policy needs to be reformed and revitalized in the Gulf Arab States. Several reports and studies have identified the need to develop and adopt more rigorous plans to raise the level of research and development $(R \& D)$ in the region. In several of the Gulf Arab States, policy makers have sought to address this issue through establishment of new "Education Cities" wherein university campuses have been co-located with industrial parks in order to build regional knowledge economies. Many of these initiatives have attracted foreign talent and global R\&D firms. Our research aims to understand the etiology of the under-performance of the $\mathrm{R} \& \mathrm{D}$ efforts in the region. In this paper, we report on results obtained from in-person interviews with the Ministers of Education and other educators in the Gulf Arab States. We interviewed experts in the field of science and technology policy in the Gulf region to address the following major questions: 1) how can science (e.g. biomedical, agriculture, engineering) be strengthened in the Gulf Arab States; 2) how effective are the science policies enacted by regional governments in the Gulf, and how can these policies be enhanced; 3) what role do regional or international collaborations play in a research and training network system, and how can these regional partnerships be bolstered; and, 4) how can the international community assist to accelerate progress and reduce the science knowledge gap. Our results show that the under-performance of the Gulf region in science and technology appears to be due to a: 1) lack of early exposure of young adults to science, 2) low perception of the societal value of science, 3) lack of institutional (e.g. university) resources, 4) too few scientists who make science their long-term careers, 5) lack of an integrated, international research network of collaboration, and 6) lack of motivation among students.

We also report on our findings regarding the state-of-the-art of the research enterprise, and the strengths and weaknesses of the research and training environment as perceived by educators/administrators in the region.
\end{abstract}

Keywords: Education cities, Educational science policies, Gulf Arab States, Science academies, STEM demographics

\section{Introduction}

The Gulf Arab States are consumers of an arsenal of pedagogical approaches to higher education from mainly the United States and Western Europe. It has been reported that they have resources to acquire high-quality talent to teach in higher education, e.g. science and engineering, in order to train the next generation of academics (Abouammoh, 2009; Smith and Abouammoh, 2013). Many countries in the Gulf Cooperation Council (GCC), such as in Qatar and the United Arab Emirates (UAE), have strongly promoted higher education by investing financial resources to train university faculty, engineers, physicians, and physician-scientists through a series of partnerships with American universities in an attempt to develop research and educational capacity for their countries (Abouammoh, 2009; Hajjar and Gotto, 2013; Romani, 2009). These partnerships have taken the form of "Education 
Cities" which are sprawling campuses in their major cities. They are comprised of various universities and technology parks. These "hubs" of learning are examples of where the adaption of Western paradigms of education have been molded into a fabric of higher education that has become a beacon of national pride for the training of students from all over the world. These education cities now exist in Kuwait, Saudi Arabia, theUAE, and Qatar (Lane and Kinser, 2013).

For example, Education City in Qatar was founded in the late 1990s partly in response to a set of recommendations for major educational reforms by the RAND Qatar Policy Institute (Kamrava, 2013). It is the newest and largest of its type, and it has a wide spectrum of educational opportunities associated with it, including an Ivy League medical school (Hajjar and Gotto, 2013; Romani, 2009). Qatar policy makers also established the Qatar Science and Technology Park in Education City in 2008 to link some of the schools in Education City to industry. The Emir of Qatar created the Supreme Education Council to direct and control education for all ages, from the pre-school level through the university level, including the "Education for a New Era" initiative to improve the quality of education (Brewer et al., 2007). As articulated in the Qatar National Vision 2030 statement by the Emir of Qatar in 2008, these initiatives can help reduce the knowledge gap in this region of the world (Kamrava, 2013).

As they build their knowledge economies, the GCC are very motivated to emulate the American model of higher education in science (UNDP, 2003, UNESCWA, 2005). Historically, the Middle Eastern countries, including the Middle East and North Africa (MENA) region, were dominated by European-style, pedagogical approaches to science education. This influence has changed in the last 20 years owing to American and British recommendations. However, the GCC countries vary in their attempts to foster American partnerships.

Analyses of the status of science education in the Gulf region indicate that some countries have adopted, in part, the American paradigm for science education. For example, it has been pointed out by Tolmacheva (2008) that Kuwait created private universities whose governance boards decide which international partners will be chosen, while Saudi Arabia created the King Abdullah University of Science and Technology (KAUST). KAUST emphasizes many American educational values, yet there remains issues regarding cultural policies, government control and gender treatment. In Qatar, the RAND Corporation's investigation into post-secondary education recommended the creation of a liberal arts academic center with the assistance of an American liberal arts college (Tolmacheva, 2008). It is reasoned that this would create more educationally-balanced students. In the United Arab Emirates (UAE), there is a nascent post-graduate education program for scientific exchange particularly with Western universities, notwithstanding the lack of a national strategy for funding scientific research. In any event, it has been acknowledged that there is a paucity of scientists and technologists in the Gulf, that there is a lack of specific priorities related to the training of the next generation of STEM professionals, and that the key factors which will determine the success of the development of technologies will include the design of a strategy to enable R\&D to thrive and lead to useable products (Sasson, 2007).

Other Gulf countries have also professed the desire to become knowledge-based societies with less reliance on natural resources (Donn and Al Manthri, 2013). Their common objective has been to train Arab nationals to be outstanding professionals in the science and technology disciplines (Donn and Al Manthri, 2013). To achieve this goal, the Gulf Arabs have realized that for their Education Cities to thrive, they must develop a different culture in which the next generation of young Gulf Arabs will want to be engaged in the arts, ethics, science and engineering; and, to remain in this region of the world. It is important for Arab youths to appreciate the value of science. Embedded in this mindset should be a national pride to actively participate in building research capacity for their own country and not solely rely on the import of this knowledge and the talented professionals who wish to work in the Gulf for a limited period of time (Zahlan, 2012).

As defined by many scholars who have investigated the issues regarding the state of science and technology in the Gulf Arab States (Barber, 2007; Boujaoude, 2003; Nour, 2005; Sasson, 2007; Stasz, 2007; Tolmacheva, 2008), the underlying problem is that neither the Gulf nor the Mediterranean Arab countries appear to have committed sufficient resources to promote science and technology in this modern era. Our research set out to identify the reasons that define the lack of rigorous science policies in the region. We set out to determine if it is a lack of talented educators and the committed financial resources alone as some postulate, or are there other underlying, undefined issues.

The key question that policy makers are asking in this decade is the following: if the resources and physical infrastructure are available, are the policies promoting STEM areas rigorous enough; and, are they championed in such a manner to help grow the number of educated and talented citizens who may want to adopt a career in the 
sciences. Most importantly, will this mindset make a difference in the quality of life for the future. This issue became central to our investigation.

\section{Methods and Data Aggregation}

We conducted a mixed qualitative/quantitative investigation to explore the goals and strategies that high level policy makers perceive as necessary to strengthen science and technology education in the 21 st century, with particular focus on the way international relationships can support those goals and strategies. In so doing, the first and third author gained unprecedented entry to administrative level policy-makers in Qatar, Saudi Arabia, Kuwait, Oman, and the United Arab Emirates (UAE) to elicit their insights on these matters. Members of the Bahrain government elected not to participate in this study.

For the qualitative phase, we developed a set of seven questions to guide the semi-structured interviews (see Table 1). The questions were devised by the first author and refined with input from the other authors who have expertise in both international academic policy affairs and personal familiarity with Middle Eastern culture.

We recruited participants using a snowball sampling method whereby a researcher gains access to a select group through trust-building with that group's members. Outreach was done by email in which a prospective participant was asked if he would be willing to engage in face-to-face interviews with the first or third author in a location of his or her own choosing. Furthermore, the invitation explicitly noted that any interviews would not be video or audio recorded, but hand-written notes would be taken. This was due to the sensitivity of the topic, the positions of the policy-makers, and the need to develop interviewer-interviewee trust in the discussions.

One to two policy makers from each country participated in the study between 2013-2014. Interviews were conducted in their government offices. At least one additional government observer was present at each interview beyond the interviewee. Each participant was asked the same questions from the interview guide. Follow-up questions were asked to investigate the various issues raised by the informants or to ask for further clarification to an answer. The participants were asked to comment only on their own country and not on others in the region. The interviewers took hand- written field notes. Interviews averaged 90 minutes. The first- and third author's field notes and personal observations were recorded into electronic format subsequent to each interview.

The first author conducted a content analysis of each transcription to organize textual data into a rubric differentiated by question and country (See Table 1). Then, the first author as well as an independent scientist not associated with this study aggregated and transformed the data into Likert scales meant to reflect the spectrum of opportunities and challenges that the participants perceived for each country's science education system faces. Others on the research team routinely provided insights and feedback as content was organized and transformed. The scales are presented in both matrix format (See Table 2) as well as in a spider plot to facilitate interpretation (See Fig 1). The analyses enabled our team to develop an understanding of the perceived challenges and opportunities that each country faces, as described by a high-level official, as well as offer a macro assessment of the opportunities and challenges for enhancing the research enterprise in the Gulf Arab region.

In an effort to determine the relative efficacy of each country's existing science and engineering workforces, we gathered quantitative data pertaining to a variety of parameters that might reflect the extent of the scientific enterprise, such as the patents awarded (Fig. 2) and scientific papers published (Fig. 3) within each country. Furthermore, to gauge the effects of what the interviewed ministers/educators perceived as a lack of motivation and support for STEM education, we aggregated data comparing the first degree choices of students in each country (Fig. 4), as well as a profile of the doctoral degrees awarded in the sciences in one particular Gulf State where the information was available (Fig. 5). The goal was to determine if the countries are measurably advancing the opportunities of their young scholars to pursue science careers; and, to assess each country's position to make investments in STEM areas.

GDP Per Capita data (Fig. 6) is also shown as a means to approximating the potential for the development of science education in these states. In order to reflect the success of scientists in these countries to garner the sponsorship of international organizations like UNESCO, WHO, ILO, CGIAR, and FAO, we show the proportion of total scientific publications by each country that have been published with and without such support in 1995 and 2005 (Fig. 7) (Zahlan, 2012). In Figures 8-10, the existing total enrollment per capita and student-to-teacher ratios, as well as the number of students per school at all levels of education in each country, are displayed to indicate the size and support of a new generation of students in each of these Gulf Arab countries.

Though most of our referenced studies concerned the motivations for investing in science and technology among the five countries we surveyed, there was a significant lack of data for a number of relevant indicators across all five 
countries. This included: each country's investment in science, technology, and education; salaries for scientists and teachers; and the size of the science and technology workforce. This lack of data was due to the fact that it had either not been reported in suitable form or within the time period reviewed in our studies. Others have also noted a similar lack of data. Bhandari and El-Amine found that this data shortage maybe due to any of the following reasons: "the data in question had either never been collected or had not been organized in a form that could be reported; or, institutions were reluctant to provide certain types of information such as details on the institution's funding model" (Bhandari and El-Amine, 2012).

\section{Results and Discussion}

3a. Qualitative Results: the Interviews

We conducted interviews with educators and administrators from the ministries of education in Qatar, Saudi Arabia, Kuwait, Oman, and the United Arab Emirates (UAE), and posed seven questions about their views of the state of educational polices in their countries (Table 1).

Table 1. Minister/Educator Responses to Seven Questions on General Science Policies in Their Countries

\begin{tabular}{|c|c|c|c|c|c|}
\hline Questions & Qatar & Saudi Arabia & Oman & Kuwait & UAE \\
\hline $\begin{array}{l}\text { 1. What are the } \\
\text { Main Challenges } \\
\text { to the Promotion } \\
\text { of Science? }\end{array}$ & $\begin{array}{l}\text {-Lack of } \\
\text { motivation } \\
\text {-Need to } \\
\text { Identify students } \\
\text { interested in } \\
\text { science }\end{array}$ & $\begin{array}{l}\text {-Students find } \\
\text { science too hard; } \\
\text {-Lack of } \\
\text { motivation } \\
\text {-Students find } \\
\text { humanities and } \\
\text { business more } \\
\text { interesting }\end{array}$ & $\begin{array}{l}\text {-Need more } \\
\text { robust } \\
\text { scholarship } \\
\text { programs } \\
\text {-Need stronger } \\
\text { science } \\
\text { education in } \\
\text { curriculum }\end{array}$ & $\begin{array}{l}\text {-Lack of } \\
\text { performance in } \\
\text { science and } \\
\text { math } \\
\text {-Poor quality of } \\
\text { science teaching } \\
\text {-Science not } \\
\text { held in high } \\
\text { regard; }\end{array}$ & $\begin{array}{l}\text {-Lack of } \\
\text { motivation } \\
\text {-No pride } \\
\text {-Science } \\
\text { education needs } \\
\text { to be revered }\end{array}$ \\
\hline $\begin{array}{l}\text { 2. What is the } \\
\text { Effectiveness of } \\
\text { the Existing } \\
\text { Science Policies? }\end{array}$ & $\begin{array}{l}\text {-Not rigorous } \\
\text { enough } \\
\text {-Need to train } \\
\text { better teachers at } \\
\text { all levels }\end{array}$ & $\begin{array}{l}\text {-Moderately } \\
\text {-Yes, they can be } \\
\text { enhanced through } \\
\text { KAUST }\end{array}$ & $\begin{array}{l}\text {-Not yet } \\
\text { determined } \\
\text {-Could be } \\
\text { stronger }\end{array}$ & $\begin{array}{l}\text {-Little agenda, } \\
\text { very few } \\
\text { policies in place } \\
\text {-Little vision } \\
\text { articulated }\end{array}$ & $\begin{array}{l}\text {-Moderately } \\
\text { effective } \\
\text {-Govt needs to } \\
\text { provide } \\
\text { incentives for } \\
\text { STEM students }\end{array}$ \\
\hline $\begin{array}{l}\text { 3. What is the } \\
\text { Role of Regional } \\
\text { Collaborations in } \\
\text { the Research } \\
\text { Network? }\end{array}$ & $\begin{array}{l}\text {-Help the } \\
\text { Qatari's } \\
\text { understand the } \\
\text { value of science }\end{array}$ & -Minor role & $\begin{array}{l}\text {-Minor role; } \\
\text { Oman govt } \\
\text { needs to } \\
\text { support science } \\
\text { more } \\
\text { vigorously }\end{array}$ & $\begin{array}{l}\text {-Lack of } \\
\text { collaborative } \\
\text { links } \\
\text {-Owing to } \\
\text { rivalries, few } \\
\text { collaborate }\end{array}$ & $\begin{array}{l}\text {-Role is } \\
\text { moderate } \\
\text {-Need to develop } \\
\text { more regional } \\
\text { conferences }\end{array}$ \\
\hline $\begin{array}{l}\text { 4. How Can the } \\
\text { International } \\
\text { Community Help } \\
\text { to Reduce the } \\
\text { Science } \\
\text { Knowledge Gap? }\end{array}$ & $\begin{array}{l}\text {-Assist the } \\
\text { educators in } \\
\text { their curriculum } \\
\text { development }\end{array}$ & $\begin{array}{l}\text {-Help develop } \\
\text { research } \\
\text { collaborations }\end{array}$ & $\begin{array}{l}\text {-By accepting } \\
\text { Omani students } \\
\text { in their research } \\
\text { training } \\
\text { programs } \\
\text { outside of } \\
\text { Oman }\end{array}$ & $\begin{array}{l}\text {-Help them } \\
\text { develop science } \\
\text { policies and } \\
\text { research and } \\
\text { training network } \\
\text {-Develop a } \\
\text { Higher Council } \\
\text { for Research }\end{array}$ & $\begin{array}{l}\text {-Recommend } \\
\text { scholars to come } \\
\text { to their } \\
\text { universities }\end{array}$ \\
\hline $\begin{array}{l}\text { 5. How Do You } \\
\text { Get the Funding } \\
\text { Agencies to } \\
\text { Support Science } \\
\text { Education? }\end{array}$ & $\begin{array}{l}\text {-Do not need } \\
\text { other funding } \\
\text { agencies }\end{array}$ & $\begin{array}{l}\text {-Difficult to do } \\
\text { since the gov't } \\
\text { funds and } \\
\text { regulates the } \\
\text { dispersal of funds }\end{array}$ & $\begin{array}{l}\text {-Everything is } \\
\text { govt supported } \\
\text { so no new } \\
\text { agencies are } \\
\text { needed to } \\
\text { support science }\end{array}$ & $\begin{array}{l}\text {-Explain to the } \\
\text { state to fund } \\
\text { more science } \\
\text { opportunities } \\
\text {-There are no } \\
\text { funding agencies } \\
\text { other than gov't }\end{array}$ & $\begin{array}{l}\text {-Senior } \\
\text { academic } \\
\text { officials } \\
\text { recommend to } \\
\text { govt officials to } \\
\text { support science }\end{array}$ \\
\hline
\end{tabular}




\begin{tabular}{|c|c|c|c|c|c|}
\hline $\begin{array}{l}\text { 6. How Do } \\
\text { Students Get } \\
\text { Exposed to } \\
\text { Science Careers? }\end{array}$ & $\begin{array}{l}\text {-Scholarship } \\
\text { opportunities }\end{array}$ & $\begin{array}{l}\text {-From programs } \\
\text { which are outside } \\
\text { the science sector } \\
\text { like the energy } \\
\text { industry or } \\
\text { cultural centers }\end{array}$ & $\begin{array}{l}\text {-Through } \\
\text { elementary } \\
\text { school }\end{array}$ & $\begin{array}{l}\text {-Not many } \\
\text { sources; country } \\
\text { needs a better } \\
\text { curriculum, } \\
\text { more } \\
\text { scholar-ships } \\
\text { and incentives, } \\
\text { and more } \\
\text { children's } \\
\text { science books }\end{array}$ & $\begin{array}{l}\text {-From parents, } \\
\text { teachers, books. } \\
\text { However, } \\
\text { science is not } \\
\text { valued as a } \\
\text { career }\end{array}$ \\
\hline $\begin{array}{l}\text { 7. Would Special } \\
\text { Academies Like } \\
\text { Boarding Schools } \\
\text { Which Emphasize } \\
\text { STEM Areas Be } \\
\text { Helpful? }\end{array}$ & $\begin{array}{l}\text {-Yes, since it } \\
\text { will improve the } \\
\text { image of science }\end{array}$ & -Perhaps & $\begin{array}{l}\text {-Yes, they are } \\
\text { already doing } \\
\text { this in Muscat: } \\
\text { Omani British } \\
\text { School }\end{array}$ & -Yes & -Yes \\
\hline
\end{tabular}

In the first question, the interviewees were asked about what they viewed as the main challenges to the promotion of the STEM areas among their youth. Almost unanimously, the respondents stressed a lack of motivation and the lack of a robust science curriculum in elementary school, high school, and college. We found that the STEM areas are not preferred as areas of study in general in the Gulf but rather business and the humanities were the more favored topic areas to study (Brewer at al., 2007).

The second question involved the effectiveness of the existing policies in place in each Gulf Arab State to train the next generation of Arab scientists and engineers. The general consensus was that the existing policies were not rigorous enough, and that the curricula did not challenge the students.

The third question focused on the central concept involving collaborative science, and the existing role of "regional" research networking within the scientific communities. Those in leadership roles in education in Qatar, for example, strongly believe that collaborations are important for research and training, and that they can accentuate the value of science in their country. The other Gulf State ministers were less sure of the need for a vast network of collaborators, believing this approach has a minor role. Rather, they opined strongly that international networking in and out of the Gulf Arab States was uncommon but would be valuable if it could be developed with the greater international community outside the Middle East. The Ministers/educators believed that the international community could assist with curriculum reform and help design visiting scholars programs (Questions 4 and 5). Supporting this finding, Bhandari and El-Amine (2012) also reported that overall, Arab institutional involvement in research at the international level is relatively low compared to Asia or Europe but that it should be improved.

Regarding the sources of support for scientific research, the Gulf Arab States do not have multiple sources of funding agencies to draw from, but rather much of the scientific enterprise is government supported. There is little philanthropy from the general population in terms of scholarships or fellowships, and little in the way of private investment in R \& D. Based on the general answers we received for our last questions (Questions 6 and 7), there appears to be limited exposure to the benefits of choosing an education in the STEM areas except from advertisement of limited scholarships and parental/teacher discussions. The informants clearly articulated a need for the students to be better exposed to science education; and, that any motivated or gifted student should have an opportunity to attend special academies such as boarding schools devoted to the STEM areas that will help them develop their interest and skillsets.

Using the responses to our seven questions (Table 1), we defined scoring criteria from numbers 1 to 5 (Table 2). High numbers denote minor or few challenges to the promotion of STEM areas, and low numbers signify non-existent policies culminating in poor advancements to the promotion of STEM areas. We used this criterion to assign numbers to each answer we received for each question, and the results are shown in a composite diagram as a spider plot (Fig. 1). 
Table 2. Criteria for Scoring the Answers to the Seven Questions in Table 1 on Science Education Policies

\begin{tabular}{|c|c|c|c|c|c|}
\hline QUESTIONS & Score 1 & Score 2 & Score 3 & Score 4 & Score 5 \\
\hline $\begin{array}{l}\text { 1. What are the } \\
\text { Main Challenges } \\
\text { to the Promotion } \\
\text { of Science? }\end{array}$ & $\begin{array}{l}\text { Significant, No } \\
\text { Motivation, Poor } \\
\text { Teaching }\end{array}$ & $\begin{array}{l}\text { Attempts Have } \\
\text { Been made to } \\
\text { Improve }\end{array}$ & $\begin{array}{l}\text { Some } \\
\text { Motivation; } \\
\text { Language issues } \\
\text { are a problem }\end{array}$ & $\begin{array}{l}\text { Showing } \\
\text { Advanced } \\
\text { Scholarship }\end{array}$ & $\begin{array}{l}\text { Minor } \\
\text { Challenges }\end{array}$ \\
\hline $\begin{array}{l}\text { 2. What is the } \\
\text { Effectiveness of } \\
\text { Existing Science } \\
\text { Policies? }\end{array}$ & Non-Existent & $\begin{array}{l}\text { Poor, Lack } \\
\text { Rigor }\end{array}$ & Moderate & Contemporary & $\begin{array}{l}\text { Rigorous, } \\
\text { Well-Developed }\end{array}$ \\
\hline $\begin{array}{l}\text { 3. What is the } \\
\text { Role of Regional } \\
\text { Collaborations } \\
\text { in the Research } \\
\text { Network? }\end{array}$ & None & $\begin{array}{l}\text { Starting } \\
\text { development }\end{array}$ & $\begin{array}{l}\text { Organizing } \\
\text { conferences to } \\
\text { generate ideas }\end{array}$ & $\begin{array}{l}\text { Strategic } \\
\text { Planning is } \\
\text { almost complete }\end{array}$ & $\begin{array}{l}\text { Developed } \\
\text { regional and } \\
\text { international } \\
\text { network }+ \\
\text { Education Cities }\end{array}$ \\
\hline $\begin{array}{l}\text { 4. How Can the } \\
\text { International } \\
\text { Community } \\
\text { Help to Reduce } \\
\text { the Science } \\
\text { Gap? }\end{array}$ & $\begin{array}{l}\text { Would need to } \\
\text { develop } \\
\text { curriculum and } \\
\text { state of the art } \\
\text { labs }\end{array}$ & $\begin{array}{l}\text { Planning stages } \\
\text { for the } \\
\text { curriculum and } \\
\text { the labs }\end{array}$ & $\begin{array}{l}\text { Curriculum } \\
\text { changes are in } \\
\text { place, but few } \\
\text { labs are up and } \\
\text { running }\end{array}$ & $\begin{array}{l}\text { Raising funds } \\
\text { for lab } \\
\text { development }\end{array}$ & $\begin{array}{l}\text { International } \\
\text { collaborations } \\
\text { fully developed }\end{array}$ \\
\hline $\begin{array}{l}\text { 5. How Do you } \\
\text { Get Funding } \\
\text { Agencies to } \\
\text { Support Science } \\
\text { Education? }\end{array}$ & Impossible & $\begin{array}{l}\text { Maybe it is } \\
\text { possible }\end{array}$ & $\begin{array}{l}\text { Some } \\
\text { discussions have } \\
\text { started }\end{array}$ & $\begin{array}{l}\text { Strategic } \\
\text { Planning and } \\
\text { Development is } \\
\text { being conducted }\end{array}$ & $\begin{array}{l}\text { Gov't leadership } \\
\text { is fully engaged }\end{array}$ \\
\hline $\begin{array}{l}\text { 6. How Do } \\
\text { Students get } \\
\text { Exposed to } \\
\text { Science Careers? }\end{array}$ & $\begin{array}{l}\text { There is no } \\
\text { exposure of } \\
\text { significant merit }\end{array}$ & $\begin{array}{l}\text { At the planning } \\
\text { stage }\end{array}$ & $\begin{array}{l}\text { Delayed } \\
\text { implementation }\end{array}$ & $\begin{array}{l}\text { Some exposure } \\
\text { in elementary } \\
\text { schools }\end{array}$ & $\begin{array}{l}\text { Very early in } \\
\text { their careers; } \\
\text { scholarships are } \\
\text { available }\end{array}$ \\
\hline $\begin{array}{l}\text { 7. Would } \\
\text { Special } \\
\text { Academies Like } \\
\text { Boarding } \\
\text { Schools which } \\
\text { Emphasize } \\
\text { STEM areas be } \\
\text { Helpful? }\end{array}$ & Highly unlikely & Possible & $\begin{array}{l}\text { Likely but } \\
\text { Nothing in Place }\end{array}$ & $\begin{array}{l}\text { Yes, initiated } \\
\text { already }\end{array}$ & $\begin{array}{l}\text { Yes, already } \\
\text { exists and } \\
\text { proven to be } \\
\text { helpful }\end{array}$ \\
\hline
\end{tabular}




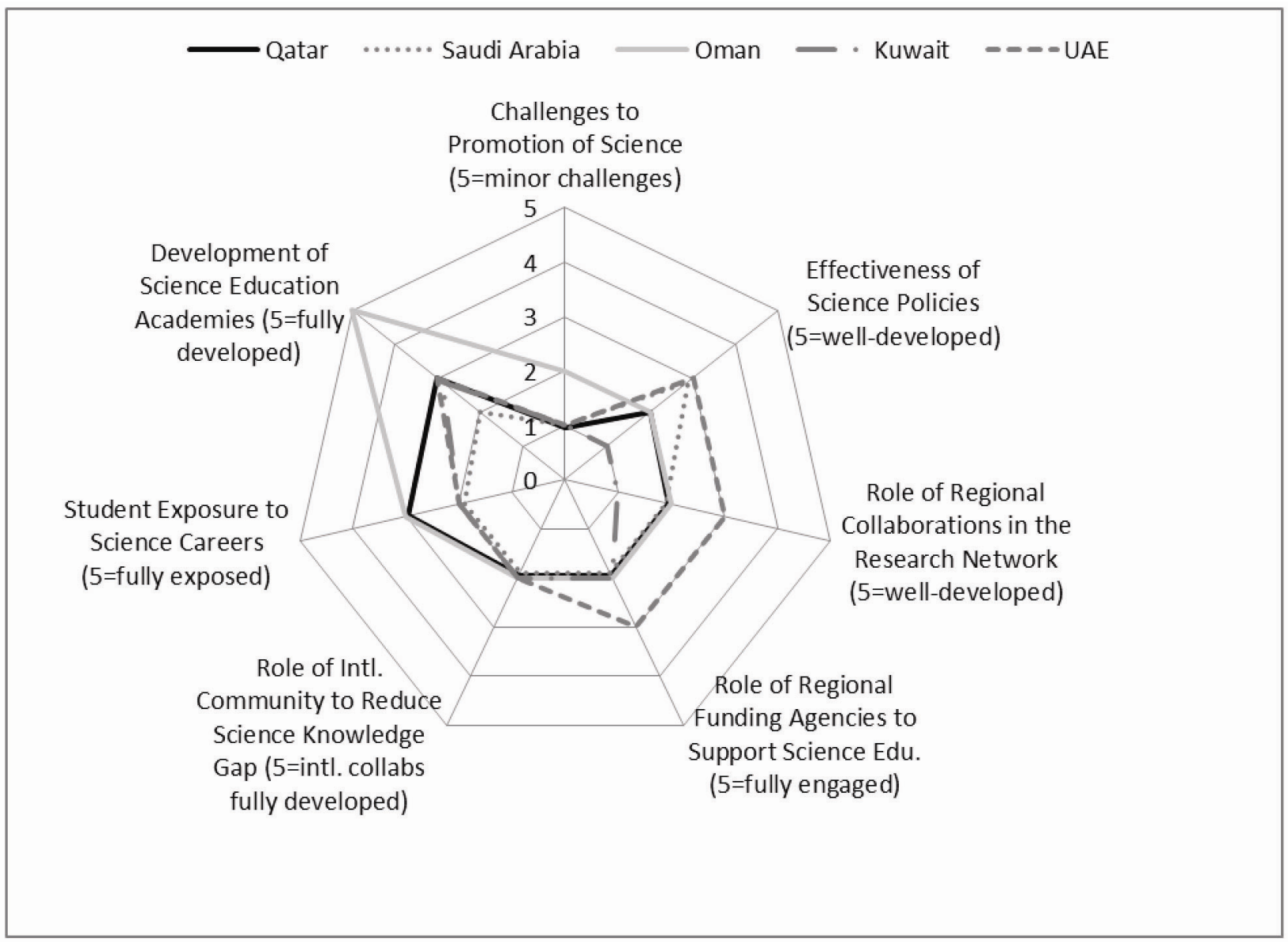

Figure 1. Scoring Diagram of the GCC Minister/Educator Responses to the Seven Questions

Our data shows that for the most part the majority of Gulf States are in a similar position with respect to the development of science education. Oman appears to have a more robust approach to the promotion of special academies focused on science education since they have been more proactive in the identification of students early in their careers who are truly interested in science.

Overall, it is clear from Figure 1 that there are challenges in all Gulf States in advancing science education and research. There is a strong need to develop rigorous education policies to address all areas of weakness, albeit the GCC governments have elected to focus only on a few areas. Their investment in capital and talent should not center only on the recruitment of the international community, but rather a set of national priorities should be developed to make it attractive for Gulf Arab students to pursue advanced educational training, and to take full advantage of their governments' generous investments in building research and education capacity.

As a promising first step, the Gulf Arab governments have set up foundations in their countries to support education, science and community development, which direct the resources of the government to academic units in elementary and secondary schools and colleges. Based on the interviews, the Ministers of Education appear very committed to socio-economic development in their countries. However, this combination of political will and financial resources must be leveraged to enact strong policies for advancing education in STEM areas.

Most of the ministers of higher education whom we interviewed would like to see the establishment of: 1) educational academies for those interested in science at a very early age to help motivate and train them for a lifelong career in science; 2) scientific prizes or awards to recognize the talented students who show innovative and thoughtful approaches to addressing scientific problems; and, 3) financial incentives to pursue a career in science. Many others in higher education in the Gulf region believe that TV/radio programs should also be oriented toward educating the public to the many advances made in the STEM areas. 
3b. Quantitative Results

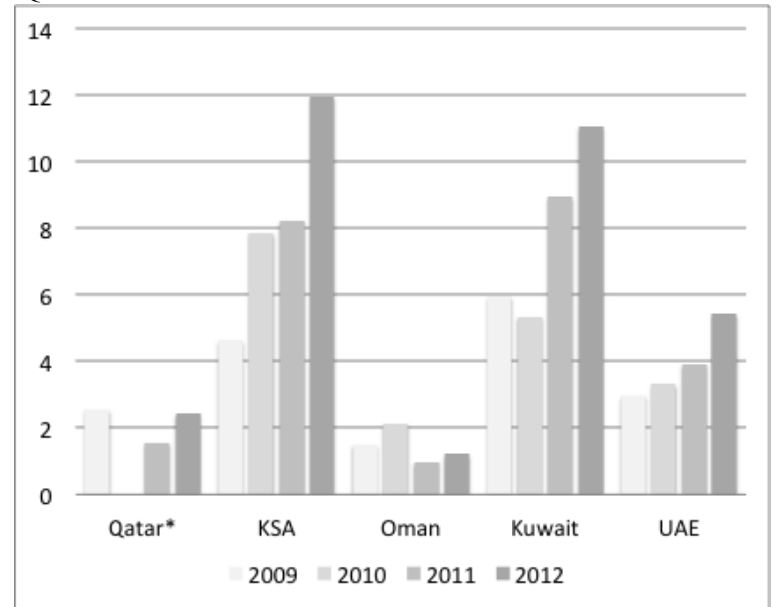

Figure 2. Total Patents Awarded per 1 Million People, by Year (Direct and PCT National Phase Entries, By Applicants' Origin)

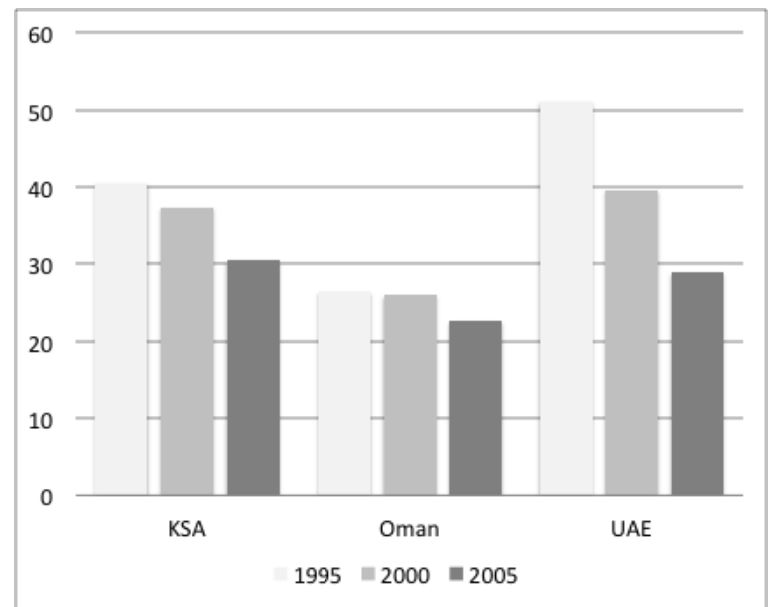

Figure 3. Articles Published in all Science and Engineering Fields, Per 1 Million People, in 1995, 2000,2005

*no data reported for Qatar in 2010

Sources: Figure 2: World Intellectual Property Organization (WIPO), World Intellectual Property Indicators, 2012 Edition; Figure 3: National Science Board, Science and Engineering Indicators 2008; Population data from World Bank Open Data, 2014.

As we see in Figure 2, the Kingdom of Saudi Arabia (KSA) and Kuwait stand out amongst all the countries in the Gulf Arab world as having the most patents per capita in years 2009 to 2012. Interestingly, the KSA rated the effectiveness of their science policies as moderate so we rated their response as a "3" (see Fig. 1), while Kuwait reported a lack of vision, agenda, and existing policies (see Fig. 1; rated a 1). The UAE, like KSA and Kuwait, followed an upward trend over that four-year period. Oman stands out as the country with the lowest year-to-year number of patents per capita in this category.

In Figure 3, the UAE reported the highest number of STEM articles published in the group, with Kuwait and Qatar not reporting any data on this topic in 1995, 2000, and 2005. The UAE also gave the most, or tied for most, favorable reports (see Fig. 1, scores of 3 ) for the role of regional funding agencies to support science education, the role of regional collaborations in the research network, the effectiveness of science policy, and the development of science education academies. KSA, which also scored a 3 (Figure 1) in their appraisal of science policy effectiveness, observed a lower and declining number of science and engineering articles published over these years, with less than half as many papers per capita in 2005 than the leader, UAE. It is noteworthy in the discussion of this per capita value that the KSA also has the highest population of the GCC group.

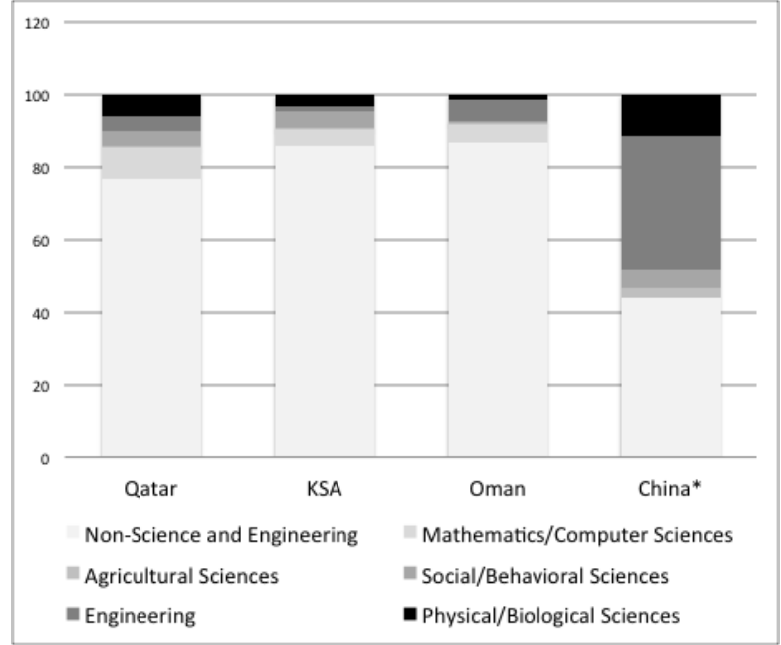

Figure 4. Distribution of First University Degrees Earned in 2004, by Percent

* Mathematics/Computer Science Data not available for China

Sources: Figures 4 and 5: National Science Board, Science and Engineering Indicators 2008. 
The distribution of first university degrees earned in 2004 (Fig. 4) shows how the Gulf Arab State cohort compares with China, a large country with rapidly developing science and technology. Of the Gulf countries reporting (i.e. Kuwait and UAE not included), Qatar gave the highest number of first degrees in science and engineering (23\%). Oman reported the lowest at $13 \%$. China, by comparison, gave $56 \%$ of first degrees in science and engineering, with the most of those (37\%) in engineering.

In Figure 5, we show the profile of science and engineering doctoral degrees earned in the KSA at the graduate level. The figure shows that the majority of these degrees were given in the physical/biological sciences ( 88 in the year), followed by engineering (53), and social/behavioral sciences (48).

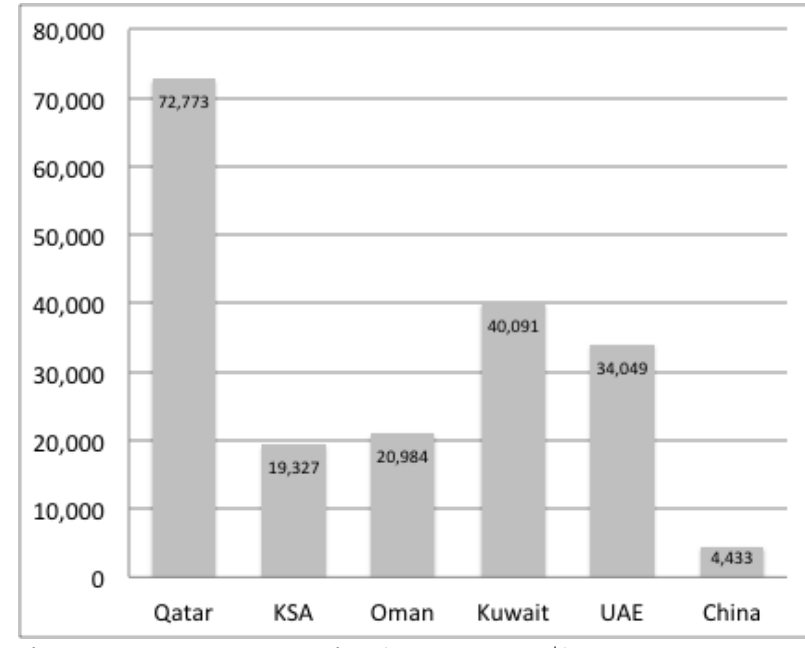

Figure 6. GDP Per Capita (Current US\$), 2010

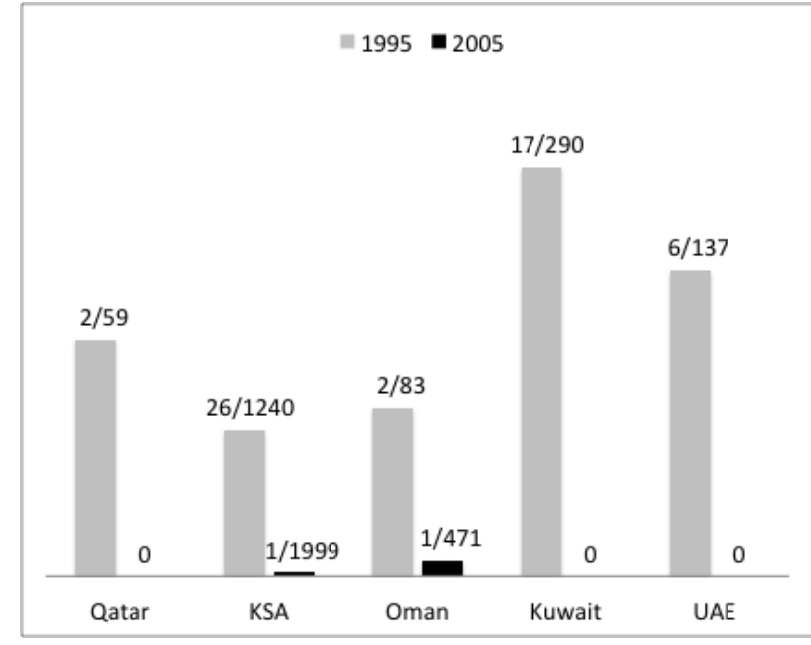

Figure 7. Fraction of Scientific Publications Completed with Sponsorship by International Organizations

Sources: Figure 6: World Bank Open Data, 2014.

Figure 7: Zahlan, Science, Development, and Sovereignty in the Arab World, 2012.

Relevant to this discussion is the gross domestic product (GDP) per capita for each country in the group (Fig. 6). As this figure shows, Qatar reported a far higher GDP per capita in 2010 (\$72,773 USD) than did the rest of the Gulf Arab States, with the next highest, Kuwait, at $\$ 40,091$ and the remaining three (UAE, Oman, and KSA) reporting GDPs per capita less than half of that of Qatar. By comparison, China reported a far lower 2010 GDP per capita of $\$ 4,433$.

Figure 7 reflects the very limited and declining level of involvement that these countries have in research programs funded by international organizations. This agrees with the low score (a 2 from all countries) given by each interviewee to estimate the role of the international community in reducing gaps in scientific knowledge. In all countries, the involvement of these international organizations declined significantly between 1995 and 2005, with only two papers from the whole cohort having been published with sponsorship from international organizations like UNESCO and WHO in 2005. This decline occurred notwithstanding an otherwise significant increase in research activity over this period. 
For all figures 8 through 11: $\square$ Private, Government

\section{Primary Schools}

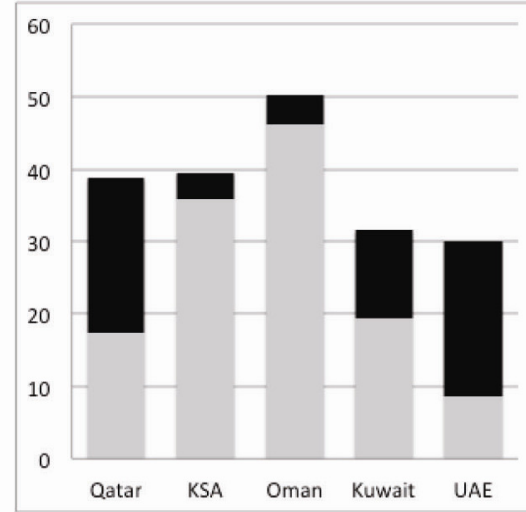

Figure 8.a. Total Students in Primary School, 2009-2010 (Per 100 People Ages 0-14, 2009)

*Oman Private Includes Intermediate

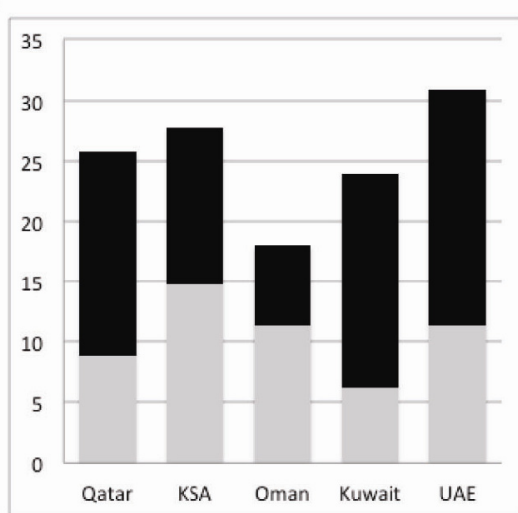

8.b. Student: Teacher Ratio in Primary School, 2009-2010

*Oman Private Includes Int, Sec

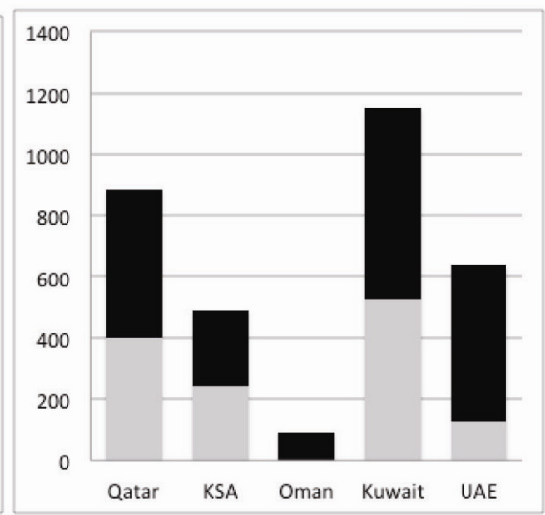

8.c. Students per Primary School, 2009 $-2010$

*Oman School data includes Int, Sec

*Oman Govt School data N/A

* UAE School data includes Int, Sec

Source: The Cooperation Council For the Arab States of Gulf Secretariat General, Statistical Bulletin, 2012; Population data from World Bank Open Data, 2014.

Figures 8.a and 8.b show that Oman had the most students per capita and lowest ratio of students to teachers at the primary school level in the 2009-2010 year, while Figure 8.c shows that the KSA had the fewest students per school. UAE reported low numbers for enrollment and high student-to-teacher in government schools.

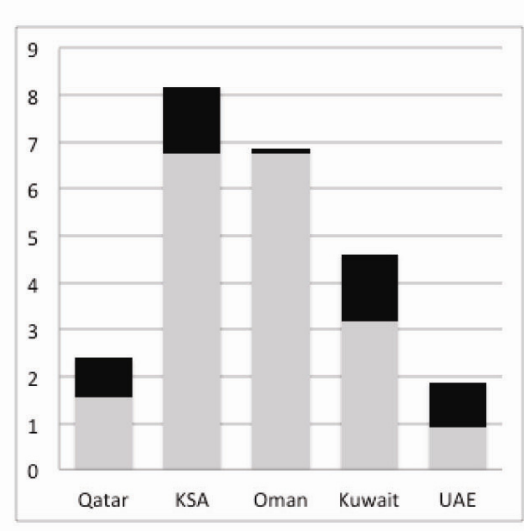

Figure 9.a. Total Students in Secondary School, 2009-2010 (Per Ages 100 People 15-64, 2009)
Secondary Schools

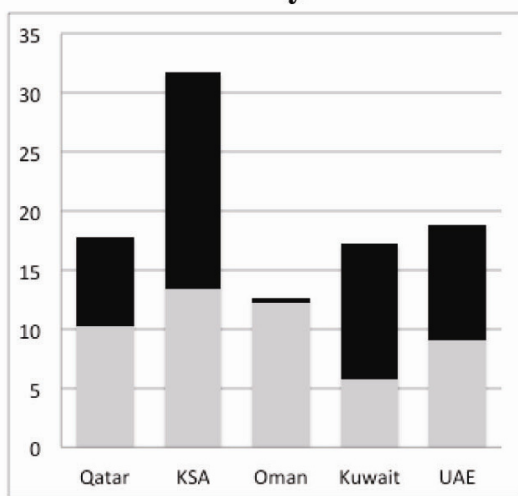

9.b. Student: Teacher Ratio in

Secondary School, 2009-2010

*Oman Private Includes Prim, Int

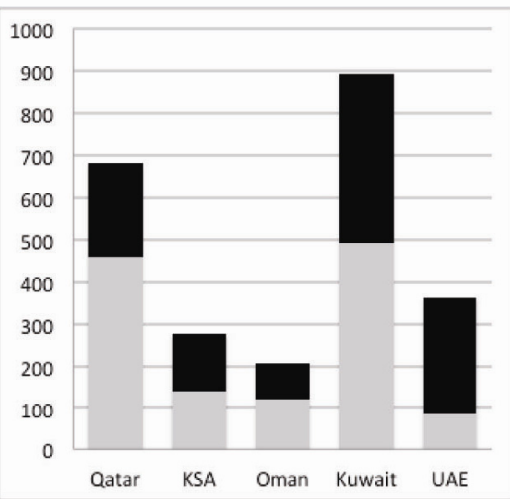

9.c. Students per Secondary School, $2009-2010$

*Oman School data includes Prim, In

*UAE School data includes Int, Sec

Source: The Cooperation Council For the Arab States of Gulf Secretariat General, Statistical Bulletin, 201: Population data from World Bank Open Data, 2014.

The overall pattern across the Gulf States at the secondary school level was consistent with that of the primary level. Though Oman is shown as having the fewest students per school in Figure 9.c, this may not be an accurate reflection of the secondary school level, as this value for number of schools includes primary and intermediate schools. The KSA was among the lowest in the students per school category, as it was at the primary level. As with the primary 
school enrollment levels shown in Figure 8.a, Figure 9.a shows that the KSA and Oman are the leaders in enrollment at the secondary level. As with the primary level (see Fig 8.b), Oman, Kuwait, and the Qatar had the lower values for student-teacher ratio at the secondary level (Fig 9.b). During the interviews, the representatives from Oman and Qatar were the most positive regarding their students' exposure to science, providing answers that qualified as a score of 2, where all other representatives' answers were a 1.

\section{Universities}

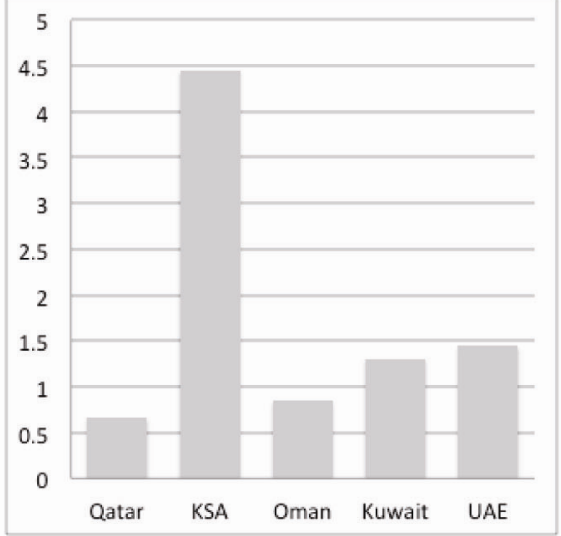

Figure 10.a. Total Enrollment in Government Universities, 20092010 (Per 100 People Ages 15-64, 2009)

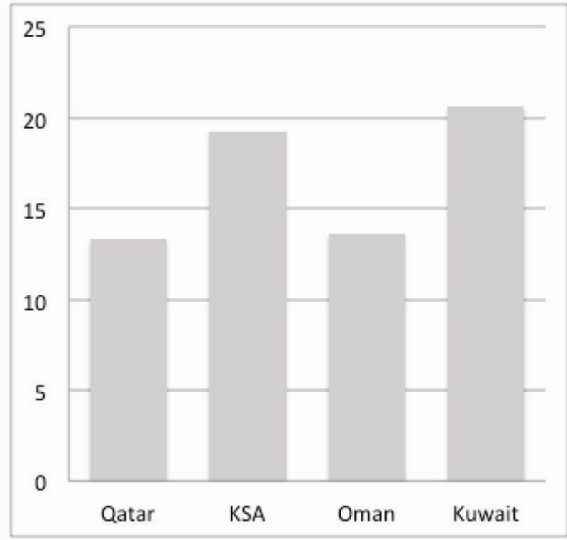

Figure 10.b. Student: Teacher Ratio in Government Universities, 2009-2010

*UAE data not available

Source: The Cooperation Council For the Arab States of Gulf Secretariat General, Statistical Bulletin, 2012; Population data from World Bank Open Data, 2014.

Figure 10a indicates high per capita enrollment in government universities for the KSA. Qatar reported the lowest numbers in enrollment, and also had the lowest student-to-teacher ratio (Figure 10.c). In 2010 there were 13 government universities in Qatar, 24 in the KSA, 6 in Oman, 8 in Kuwait, and 64 in the UAE (Cooperation Council for the Arab States of Gulf Secretariat General, 2013). This statistic, along with the data from Figure 10.c, may be misleading since it does not reflect the size or enrollment of each university and does not include all institutes of higher education in each country. For this reason, we have chosen to not reflect the number of students per university in graphical form.

\section{Implications and Conclusions}

Both foreign consultants and Arab educators including those from the UN specialized agencies (UNESCO) and the UN Development Programs (UNDP) have concluded that R\&D and technological innovations in the Gulf Arab States need to be enhanced. The Gulf States need to increase the number of scientists and engineers in the region, increase their expenditures in the STEM areas as a percentage of their GDP, increase the number of patents filed regarding scientific and technological innovations, and increase their number of peer-reviewed scientific publications. Most likely, the solutions to the challenges of promoting and exposure to STEM areas include: 1) creating high-quality schools and science academies, 2) reforming the curriculum particularly in the area of science, 3) improving the quality of teaching, 4) developing an integrated, international research network for collaboration, and 5) improving the teaching of foreign languages, particularly English, so that students will comprehend more easily new advances in technological advancements. Taken together, these recommendations in the teaching of science and technology will help create a more scholarly environment and increase the quality of life in the Gulf, particularly in the age of new discoveries.

In summary, educational policies need to be strengthened to improve education and research in STEM areas in Gulf Arab States. While a number of initiatives, such as the establishment of Education Cities in many countries in the region are very positive developments, more needs to be done to motivate and attract Gulf Arab students to pursue studies and a career in science and engineering. Furthermore, international research networking is also essential to help advance the local, regional efforts to make advances in all aspects of STEM research. Many scholars within the international community have committed to the reduction of the STEM knowledge gap in the Gulf by creating pipelines for talented and academically qualified youth to pursue a career in the STEM areas such as student 
exchange programs and international fellowships (Davidson and Smith, 2008). The academic reciprocity between Western universities and those government agencies in the Gulf who truly want to advance science in the region can be a positive factor in creating an educational environment to train the local nationals to be at the vanguard of science. However, the Gulf Arab States will also need to vigorously develop and nurture a core group of Arab nationals who will stay in the Gulf once trained, and who can take the lead in developing science policy for the youth of their countries. Such opportunities can be realized with the creation of highly-supported research and education positions in the major universities of their countries. With the current political will from senior education policy makers and significant financial support, there is a unique window of opportunity to enact effective policies for creating a strong foundation for scientific education and research enterprise that can positively contribute to future economic diversification, development, and social welfare.

\section{Acknowledgements}

The authors wish to thank Ms. Hilary Rantisi and Professor R. Nicholas Burns at the Harvard Kennedy School of Government, Programs in the Practice of Diplomacy and the Middle East Initiatives, for their valuable suggestions and scholarly discussions related to Middle Eastern diplomacy and current educational policies in the Gulf Arab world. We are also grateful to Eelco A. Slagter, M.B.A. for his helpful suggestions in the design of our study.

Finally, we thank the Julia and Seymour Gross Foundation for their generous support which allows DPH to carry out these studies as part of his senior fellowship at the Harvard-Kennedy School of Government.

\section{References}

Abouammoh, A. (2009). The role of education: trends of reforms and EU-GCC understanding. In: The Role of Education: trends of reforms and EU-GCC understanding. Presented at the workshop entitled: The EU and GCC: challenges and prospects, held in Lund, Sweden, June 2009. [Online] Available: http://faculty.ksu.edu.sa/abouammoh/Reports\%20and\%20papers\%20in\%20HE/E\%20\%20The\%20Role\%20of\% 20Education $\% 20 \% 20$ Trends $\% 20$ of $\% 20$ Reforms\%20and\%20EU-GCC\%20Uniderstanding.pdf

Barber M., Mourshed M., and Whelan F. (2007). Improving Education in the Gulf. The McKinsey Quarterly, 2007 special education: Reappraising the Gulf States, 39-47. [Online] Available: http://abujoori.files.wordpress.com/2007/04/improve-gulf-education.pdf

Bhandari, R. \& El-Amine, A. (2012). Higher education classification in the Middle East and North Africa: a pilot study. pp 1-51New York, NY: Carnegie Corporation. [Online] Available: www.iie.org/ /media/Files/Corporate/Publications/MENA-Executive-Summary.ashx

BouJaoude, S. (2003). Science and Technology Education in the Arab world in the 21st Century. Innovations in Science and Technology Education VIII, 43-68. [Online] Available: http://unesdoc.unesco.org/images/0013/001335/133581e.pdf

Brewer, D.J, Augustine, C.H., Zellman, G.L., Ryan, G.W., Goldman, C.A., Stasz, C., Constant, L. (2007). Education for a new era: Design and implementation of K-12 education reform in Qatar. RAND-Qatar Policy Institute. Santa Monica, CA: RAND Corporation. [ONLINE] Available: http://www.rand.org/pubs/monographs/MG548:html

Cooperation Council For the Arab States of Gulf Secretariat General. (2013). Statistical Bulletin, 2012. Riyadh: Information Sector - Statistical Department, Secretariat General (volume 20). [Online] Available: http://sites.gcc-sg.org/DLibrary/index-eng.php?action=ShowOne\&BID=586

Davidson, C. \& Smith, P.M. (eds) (2008). Higher Education in the Gulf States: shaping economies, politics and culture. London, England: London Middle East Institute SOAS.

Donn, G. \& Al Manthri, Y. (eds) (2013). Education in the Broader Middle East: borrowing a baroque arsenal. Oxford, England: Symposium Books, Ltd.

Economics and Statistics Division, World Intellectual Property Organization (WIPO) (2012). World Intellectual Property Indicators, 2012 Edition. [Online] Available: http://www.wipo.int/ipstats/en/statistics/patents/.

Hajjar, D.P. \& Gotto, A.M. (2013). Launching of an American medical college in the Middle East: educational challenges in a multicultural environment. International Journal of Higher Education 2(2), 67-75. http://dx.doi.org/10.5430/ijhe.v2n2p67

Kamrava, M. (2013). Qatar: small state, big politics. Ithaca, NY: Cornell University Press. 
Lane, J. \& Kinser, K. (2013). Looking ahead: 5 international trends for 2013. Chronicle of Higher Education. Available: http://chronicle.com/worldwise/looking-ahead-5-international-trends-for-2013/31279

National Science Board (2008). Science and Engineering Indicators 2008. Two volumes. Arlington, VA: National Science Foundation (volume 1, NSB 08-01; volume 2, NSB 08-01A).

Nour, S. (2005). Science and Technology Development Indicators in the Arab Region: A Comparative Study of Gulf and Mediterranean Arab Countries. Part of United Nations University Institute for New Technologies' Discussion Paper Series, 9-35. http://dx.doi.org/10.1177/097172180501000204

Romani, V. (2009). The politics of higher education in the Middle East: problems and prospects. Middle East Brief. (Vol 36, pp 1-7) Waltham, MA: Brandeis University. [Online] Available: http://www.brandeis.edu/globalbrandeis/documents/MEB36.pdf

Sasson, A. (2007). Research and Development in the Arab States: the Impact of Globalization, Facts and Perspectives. Presented at the Regional Seminar "The Impact of Globalization on Higher Education and Research in the Arab States," Rabat Morocco, 24-25 May 2007. Unesco Forum on Higher Education, Research and Knowledge. [Online] Available: http://unescore-clic.org/node/123

Smith, L. \& Abouammoh, A (eds.) (2013). Higher Education in Saudi Arabia: Achievements, Challenges and Opportunities. (Vol. 40). New York, NY: Springer. http://dx.doi.org/10.1007/978-94-007-6321-0

Stasz, C., Eide E., Martorell, F. (2007). Post-Secondary Education in Qatar: Employer Demand, Student Choice, and Options for Policy. Doha, Qatar: Rand-Qatar Policy Institute. [Online] Available: http://www.rand.org/pubs/monographs/MG644.html

The World Bank Group. (2014). World Bank Open Data. [Online] Available: http://data.worldbank.org/

Tolmacheva, M. Bringing the American College Model to the Arabian Gulf: New Challenges for Intercultural Education. Proceedings of the 4th International Barcelona Conference on Higher Education, Vol. 6. Higher education for interculatural dialogue and multiculturalism, Barcelona, 2008. [Online] Available: http://upcommons.upc.edu/revistes/bitstream/2099/5771/1/16_pap_Tolmacheva.pdf

UNDP and Arab Fund for Economic and Social Development. Arab Human Development Report 2003: Building a Knowledge Society. $\quad$ UN, $2003 . \quad$ Anline] http://www.arab-hdr.org/publications/other/ahdr/ahdr2003e.pdf

UNESCWA. Towards an Integrated Knowledge Society in the Arab Countries: Strategies and Implementation Modalities. UN, 2005. [Online] Available: http://www.escwa.un.org/information/publications/edit/upload/ictd-05-3.pdf http://dx.doi.org/10.1057/9781137020987.0006

Zahlan, A.B. (2012). Science, Development, and Sovereignty in the Arab World. New York, NY: Palgave MacmillamBarber M., Mourshed M., and Whelan F. (2007). Improving Education in the Gulf. The McKinsey Quarterly, 2007 special education: Reappraising the Gulf States, 39-47. [Online] Available: http://abujoori.files.wordpress.com/2007/04/improve-gulf-education.pdf 